\title{
ARTERIOVENOUS ANEURYSM OF THE LUNG
}

\author{
BY
CHARLES BAKER ÁND J. R. TROUNCE
}

From Guy's Hospital

Received October 21, 1948

Arteriovenous aneurysms in the lesser circulation produce a clear-cut clinical picture and illustrate again that we do not know how commonly conditions occur until they are first described. The number reported since Rodes' paper in 1938 indicate that it is by no means rare and it is a condition that can be successfully treated. It is striking, however, that although a congenital lesion, often with obvious evidence from early years, it has so far been diagnosed almost exclusively in adults. The recent interest in cyanotic congenital heart disease, which has followed the possibility of operative treatment, may well reveal further cases as it did in the examples here described. It is to stress the importance of earlier recognition of a treatable condition that we are reporting two cases and reviewing the present knowledge of this disease.

\section{The First CASE}

D. C., aged 27, was referred to Guy's in September 1947 as a case of cyanotic congenital heart disease to see if he was suitable for a Blalock-Taussig operation. He was the youngest of five children and there was no history of a similar condition in his family. Cyanosis, which was gradually and steadily progressive, was noticed at the age of 4, and a year later a diagnosis of congenital heart disease was made. His school life was restricted more by medical advice than by ill-health or disability. At 14 he left school and worked first as an errand boy using a bicycle, but after a year he was forced to take less active employment. His working life finished at the age of 19 when he was a shop assistant-work that he could do without distress-and at this time he was still cycling five miles a day. One day he tripped up in the shop and fell, and this accident was mis-diagnosed by his employer as a fit. He was dismissed as a potential liability. His cyanosis, which was by now extreme, prevented his finding other employment, much as he desired and sought it, and he remained at home until September 1947, when hope of relief for his supposed congenital heart condition brought him to hospital. In this eight years there was gradual deterioration of his condition. A year before he was seen he had tried to cycle again and found he could barely manage a mile, and by the time he was admitted he could only walk 100 to 400 yards on the level. Edema of the ankles had been almost continuous for the last four years and there was cough without sputum. In 1943 he was admitted to hospital with nose bleeding and this had continued at intervals particularly in hot weather. For the last two years he had attacks about once a month, particularly after bending down, when he felt weak "with a film over the left eye and sizzling in the ears "; there was no giddiness or loss of consciousness and the attack lasted ten minutes. Careful questioning could not elicit any story of hæmoptysis. He did not squat on his haunches when breathless or distressed.

On examination he was a spare well-built man, $5 \mathrm{ft} .7 \mathrm{in}$. in height and $112 \mathrm{lb}$. in weight. He was grossly cyanosed with a blotchy, pitted face as seen in seborrhæic subjects; there was very marked clubbing of fingers and toes (Fig. 1 and 2). He was breathless on slight exertion but there was no orthopnœa. His neck veins were not distended, the liver was just palpable but not tender; the lung bases did not sound wet, but there was slight pitting œdema of the ankles. The pulse was regular. The heart showed no clinical enlargement, which is not against a diagnosis of Fallot's tetralogy but with this in mind one was surprised to find an absence of any murmur; pulsation in the second left intercostal space was the only finding of note. The blood pressure was $105 / 80$ in the arms and 170/110 in the legs. Screening showed a heart slightly enlarged $(13 / 25 \mathrm{~cm}$.) with the pulmonary conus prominent and an enlarged right ventricle. In the right lower lung field was a circumscribed shadow with a well-defined margin, calcified in its lower and 


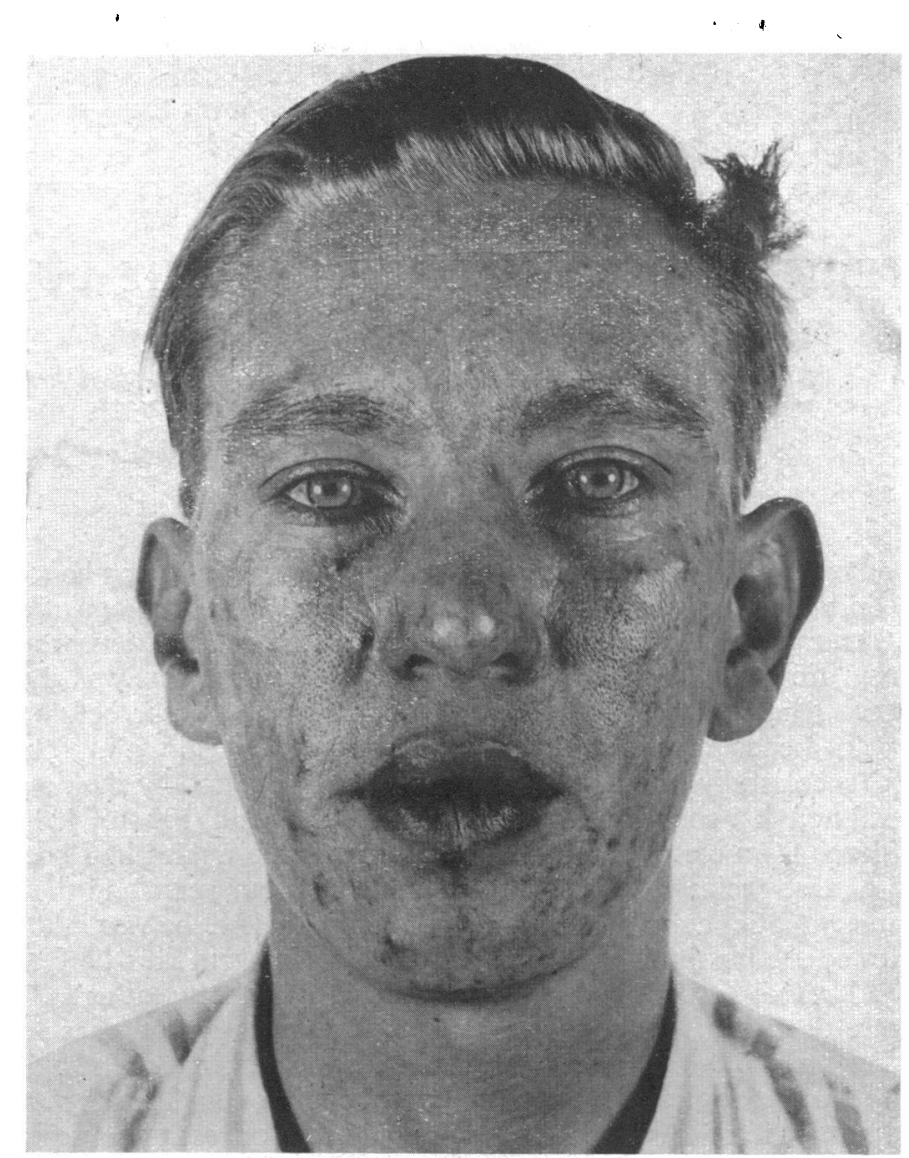

lateral part. This was connected to the right hilum by a well-marked vascular shadow and there was pulsation from hilum to the tumour, which itself did not appear to pulsate; the vessels of the left hilum were not increased (Fig. 3A). The electrocardiogram (Fig. 7) showed marked right axis deviation with broad and prominent $\mathbf{P}$ waves in leads I and II and an inverted T in lead III.

After the shadow in the lung had been seen, the two important points needed to clinch the diagnosis of arteriovenous aneurysm were looked for, and found. On listening at the right base posteriorly there was a well-marked localized systolic murmur, but no diastolic element. Angiomata were found on the inner side of the lips and on the buttocks (Fig. 4) and it was clear the seborrhœic disfigurement of the face had masked further small angiomata though the smaller ones were still difficult to see owing to the intense cyanosis (Fig. 1). A diagnosis of arteriovenous aneurysm of the lung was made, and he was admitted in February 1948 for further investigation with a view to operative treatment.

The blood picture showed marked polycythæmia with 7.5 million red cells, a hæmoglobin of 140 per cent, and a hæmatocrit of 90 ; the white cells were 8000 per cu. $\mathrm{mm}$. with a normal differential count. The circulation times were done by Dr. Allanby, the arm to tongue time with decholin being $14 \mathrm{sec}$. and arm to lung time with paraldehyde being $8.5 \mathrm{sec}$., both lying within normal limits. Probably the viscosity of the blood due to his polycythæmia nullified any tendency to a quickening of the circulation rate due to the shunt. The vital capacity was 2.5 litres. Unipolar limb and chest leads showed a vertical heart but no evidence of right ventricular hypertrophy. The blood volume was calculated by Dr. Reeve, the volume of red blood cells being measured by injecting a known amount of radioactive red cells. He points out that owing to the abnormal mixing of the blood the 


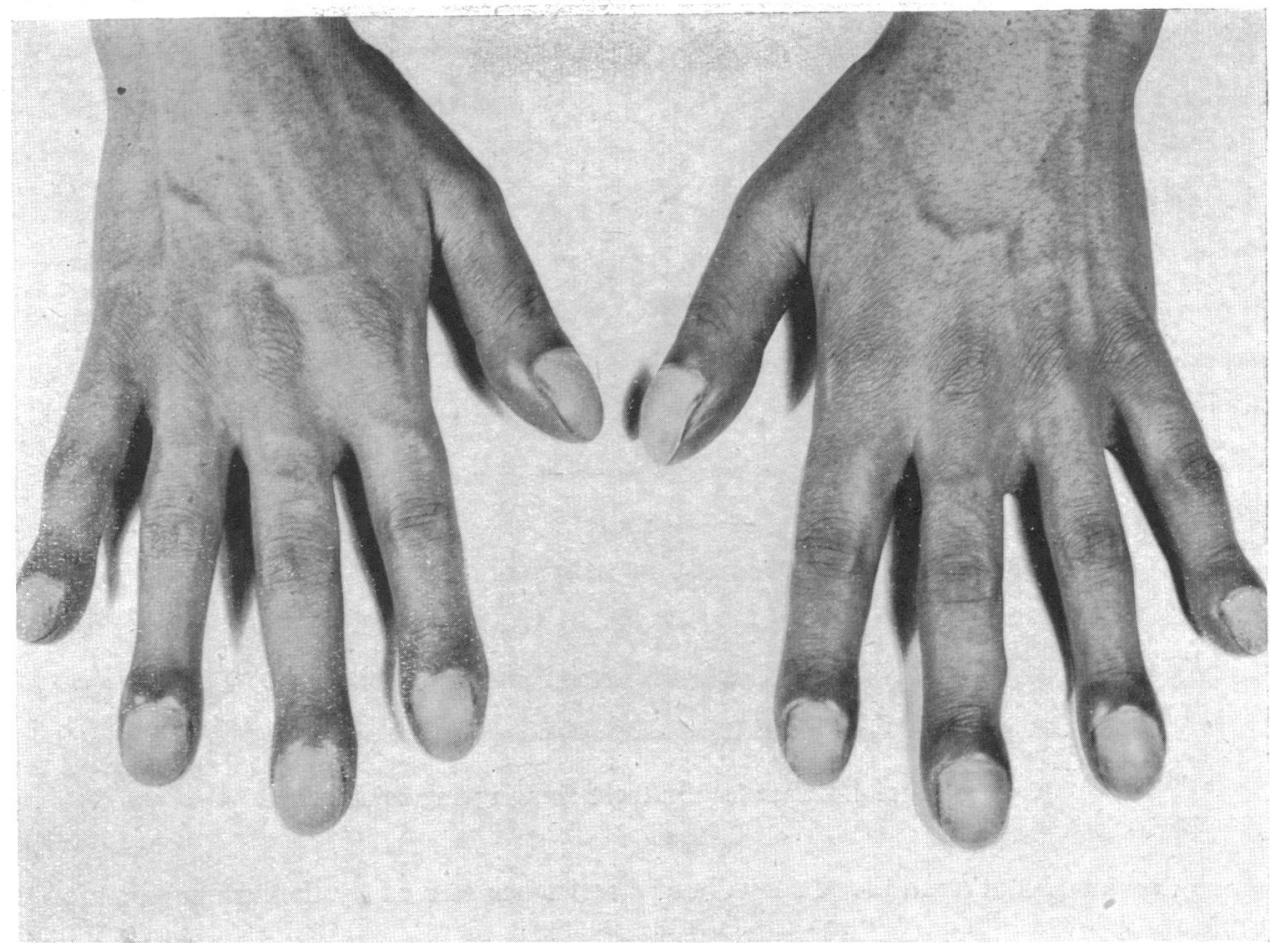

FIG. 2.-Case 1, showing clubbing of the fingers.

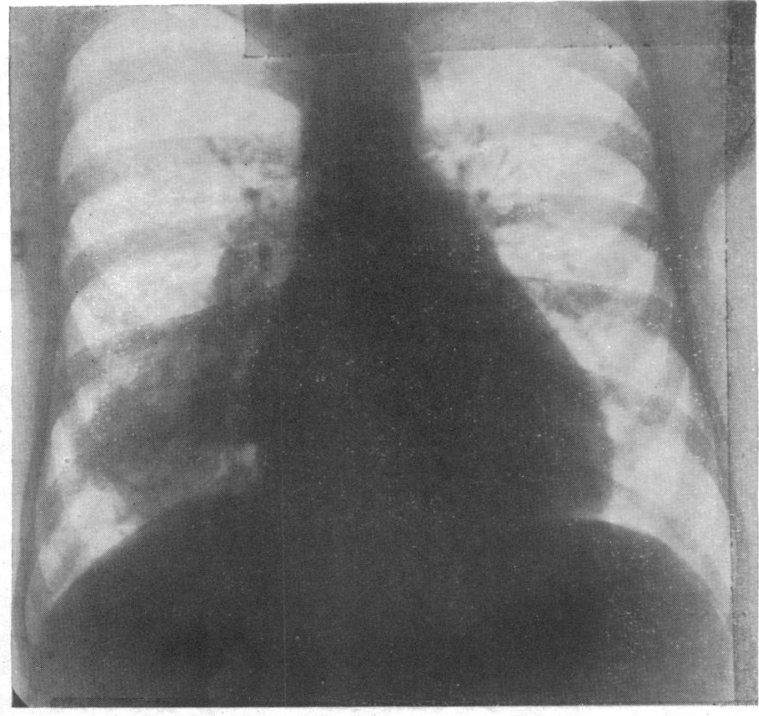

A

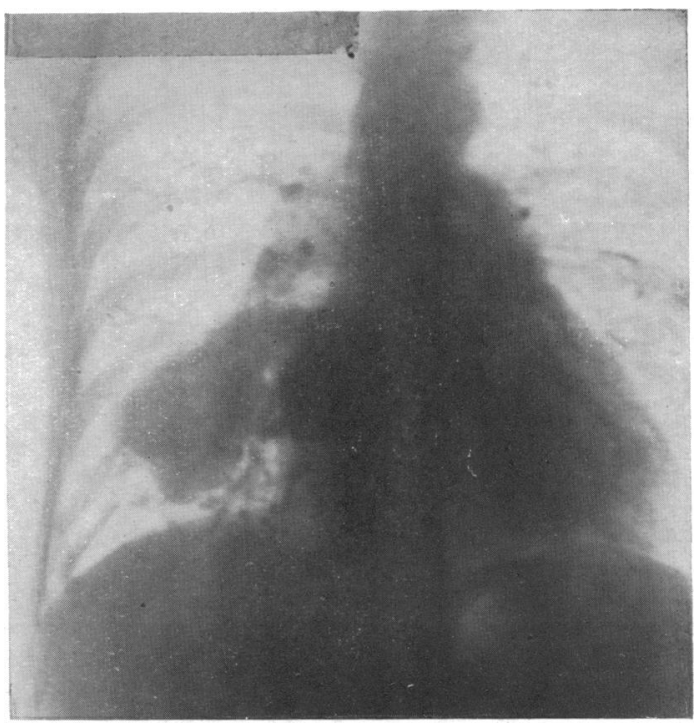

B

FIG. 3.-Case 1. (A) Straight X-ray with partly calcified aneurysm attached to right hilum by vascular shadow. (B) Angiocardiogram at 2 sec. showing two additional vascular tumours, one in the right lower zone near the mediastinum and a small one in the left lower zone behind the heart shadow. 


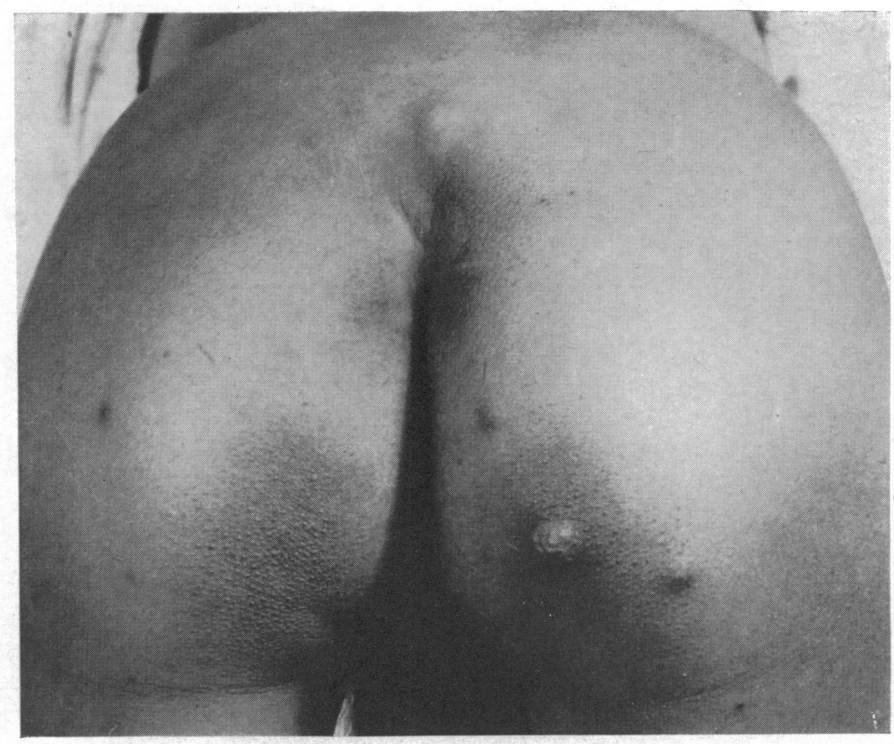

Fig. 4.-Case 1. Buttocks showing angiomata.

figures are approximate, but a red blood cell volume of $6960 \mathrm{ml}$. and a total blood volume of $8580 \mathrm{ml}$. show an increase above normal.

The angiocardiogram taken by Dr. Hills showed well the filling of the opacity previously seen and in addition two further vascular tumours, one in the right lower zone nearer the mediastinum and a small one in the left lower zone behind the heart shadow (Fig. 3B). X-ray films of hands and feet showed no pulmonary osteopathy.

Cardiac catheterization was done by Drs. H. E. Holling and G. Zak and both branches of the pulmonary artery were entered without difficulty, and the findings are summarized in Table I.

The finding of a normal pressure in the right auricle is interesting in view of the suggestion of cardiac failure furnished by the slight œdema of his ankles. The lower pressure in the right pulmonary artery may be a consequence of the lower peripheral resistance offered by the hæmangioma on that side. The general opinion that the peripheral resistance of lung vessels is negligible is against this view, but the blood was extremely viscous and the difference in peripheral resistance of the two lungs was probably great.

Estimations of the cardiac output and of the quantities of blood passing through the pulmonary hæmangiomata were made.

Cardiac Output $=$ Oxygen Consumption divided by the Oxygen Content Pulmonary Vein (Arterial Blood) minus Oxygen Content Pulmonary Artery (ml./litre.)

$$
=\frac{230}{231-212}=12 \text { litres. }
$$

Assuming that the blood passing through the pulmonary capillaries becomes 95 per cent saturated with oxygen, the pulmonary capillary circulation was estimated as $2 \cdot 6$ litres.

TABLE I

Results of Cardiac Catheterization

\begin{tabular}{|c|c|c|c|c|c|c|c|c|c|}
\hline & & & \multirow{2}{*}{$\begin{array}{l}\text { Inferior } \\
\text { vena cava }\end{array}$} & \multirow{2}{*}{$\begin{array}{l}\text { Superior } \\
\text { vena cava }\end{array}$} & \multirow{2}{*}{$\begin{array}{l}\text { Right } \\
\text { auricle }\end{array}$} & \multirow{2}{*}{$\begin{array}{c}\text { Right } \\
\text { ventricle }\end{array}$} & \multicolumn{2}{|c|}{ Pulmonary artery } & \multirow{2}{*}{$\begin{array}{c}\text { Brachial } \\
\text { artery }\end{array}$} \\
\hline & & & & & & & Right & Left & \\
\hline $\begin{array}{l}\text { Oxygen content } \\
\text { (Vol. per } 100 \mathrm{mi} .)\end{array}$ & . & . & 23.6 & $21 \cdot 1$ & 21 & $20 \cdot 6$ & $21 \cdot 2$ & $21 \cdot 3$ & $23 \cdot 1$ \\
\hline $\begin{array}{l}\text { Percentage saturation } \\
\text { Pressure, } \mathrm{mm} \text {. Hg. }\end{array}$ & $\begin{array}{l}. . \\
.\end{array}$ & $\begin{array}{l}. . \\
. .\end{array}$ & $\begin{array}{r}74 \\
8\end{array}$ & $66 \cdot 6$ & $\begin{array}{c}66 \cdot 4 \\
8\end{array}$ & $\begin{array}{l}65 \cdot 2 \\
17\end{array}$ & $\begin{array}{l}67 \cdot 1 \\
12\end{array}$ & $\begin{array}{l}67 \cdot 3 \\
15\end{array}$ & $\begin{array}{c}73 \\
105 / 80\end{array}$ \\
\hline
\end{tabular}


The pulmonary shunt equals the cardiac output less the pulmonary capillary circulation, i.e. $9 \cdot 4(12-2 \cdot 6)$ litres a minute, which is 80 per cent of the cardiac output.

This estimation of the proportion of blood passing through a shunt in the circulation is surprising, but is not impossible considering the depth of the cyanosis. It compares reasonably with estimated shunts in badly cyanosed congenital hearts and with arteriovenous fistulæ of the systemic circulation. The assumed figure of 95 per cent saturation of the blood after passage through the lung capillaries seems reasonable since the cyanosis of the patient did not lessen when he breathed oxygen. Even if a figure of 85 per cent saturation is assumed the shunt would still prove to be 70 per cent of the cardiac output.

Mr. R. C. Brock operated on April 5, 1948, with an anæsthetic of intratracheal cyclopropane and curare by Dr. Hutton. A right posterolateral thoracotomy found the upper and middle lobes free but the lower lobe was bound down to the chest wall and diaphragm by many collateral vessels. Some calcification could be felt on the surface and within the substance of the lower lobe, which also showed expansile pulsation and a thrill and was supplied by a very large artery, approximately $2 \mathrm{~cm}$. in diameter. During the course of the operation the right middle lobe bronchus was wounded and it was therefore necessary to remove both the right lower and middle lobes. This was very difficult, partially hecause of the multiple vascular adhesions to the chest wall and diaphragm and partially due to the incomplete interlobar fissures, and as a result there was considerable blood loss. Before the removal of the tumour the patient's condition was poor, his systolic blood pressure was between 70 and 80 and was not improved either by transfusion or by bronchoscopic clearance of his normal lung. However, after right and middle lobes had been successfully removed he partially recovered, his blood pressure rising to $85 / 50$ and his cyanosis disappearing. The operation lasted five hours, and during this period he received 3 pints of plasma and 1.5 pints of blood.

On returning to the ward his condition failed to improve, although his colour remained good and there was now no evidence of cyanosis; his systolic blood pressure did not rise above 90 , his respirations were shallow, bubbling and stertorous, and he was deeply unconscious. X-ray of his chest showed complete collapse of his right upper lobe and on bronchoscopy a few $\mathrm{ml}$. of mucoid material were aspirated. In spite of a transient improvement with this measure he lapsed into deeper coma and died some thirty hours after operation.
Necropsy was done by Dr. F. Camps, on April 7; 1948, twenty-three hours after death. There was about $250 \mathrm{ml}$. of free fluid blood in the right pleural cavity and a slight extravasation into the posterior mediastinium. The remaining upper right lobe contained no air but some lymph deposits. The left lung was moderately well ærated, deeply congested, with peripheral collapse of the lower lobe where there was also a small hæmangioma. Subpleural and pericardial hæmorrhages were seen. The heart was normal with some right sided dilatation. There was gross distension of the veins of the liver but no angiomata. The kidneys were also congested with dilated veins.

The specimen removed at operation is shown in Fig. 5 and is reported on by Dr. Allanby. "The specimen consists of the right middle and lower lobes. The pleura is wrinkled due to partial collapse of the lobes, but bears no sign of inflammation. The lateral pleural surface of the lower lobe shows patches of calcification, more easily felt than seen. Some fibrous adhesions are seen upon the diaphragmatic surface. The pulmonary vein leaving the lower lobe is grossly dilated and appears to communicate with a large thin-walled loculated system of spaces. The cut surface of the lower lobe shows a multilocular hæmangioma in its substance, measuring $3.5 \mathrm{~cm}$. by $3.0 \mathrm{~cm}$. adjacent to the calcified pleura, and $4 \mathrm{~cm}$. from the main lower lobe bronchus. A branch of the pulmonary artery communicates directly with this cavernous space without capillary intervention. The surrounding lung and the middle lobe are normal. Sections showed the typical microscopic appearances of a cavernous hæmangioma."

\section{The Second Case}

J. A., aged 13, was admitted to Guy's Hospital in September 1948 with acute osteomyelitis in the middle of the shaft of the left femur; this was associated with a positive blood culture and quickly responded to treatment with penicillin. Cyanosis was noticed at 5 years and had progressed to a degree when it was obvious at rest, with marked clubbing of the fingers and toes. He had early been diagnosed as congenital heart disease and attended a special school, to which he was driven by ambulance; once there, he played football without any distress. Both parents and their three other children were normal. A provisional diagnosis of arteriovenous aneurysm of the lung as the cause of his cyanosis was made on admission by the registrar, Dr. W. D. Brinton, on the X-ray appearance of the lung (Fig. 6A) and was confirmed by the finding of a continuous murmur in the left upper chest as soon 
as the pulse slowed, and subsequently by angiocardiogram (Fig. 6B).

He was a boy of average height for his age, but spare. Cyanosis was obvious at rest, with some suffusion of the conjunctivæ, and was increased by exercise, though he was not unduly breathless. Clubbing was marked. He did not squat when tired. The heart was not enlarged clinically and on X-ray showed a prominent pulmonary conus only and a cardio-thoracic ratio of $10 / 23 \mathrm{~cm}$. There was a short systolic murmur in the first and second left spaces 2 to $3 \mathrm{in}$. from the midline and an increased pulmonary second sound. Apart from this, heard over a wide area but best appreciated $10 \mathrm{~cm}$. from the midline in the second space, was a more distant but clear continuous murmur, which could just be heard in the back above the left scapula; there was no thrill. The blood pressure was $115 / 75$. Careful search found no systemic angiomata. The hæmoglobin was 126 , with $7 \cdot 2$ million red cells and a colour index of 0.88 . The electrocardiogram (Fig. 8) showed no right axis deviation. The appearance on straight $\mathrm{X}$-ray was of a mottled opacity in the apical and subapical segments of the upper left lobe composed of rather worm-like streaks tending to radiate upwards and outwards from the hilum. That these were vascular shadows was clearly shown on angiocardiography where most of the dye was shunted through the opacity, the arterial elements being filled in two seconds and the larger venous channels in the third second. At the moment of reporting this case, for which we are indebted to Dr. Hampson, Mr. Brock has agreed to operate, but this has not yet been done.*

\section{Discussion}

It will be seen that these two cases present a clearcut clinical picture, but it is only of recent years that

* Mr. Brock successfully removed the left upper lobe containing the arteriovenous aneurysm on February 10, 1949: there was a large collateral circulation from the bronchial arteries. Following operation, cyanosis has disappeared and his physical capacity has increased. 


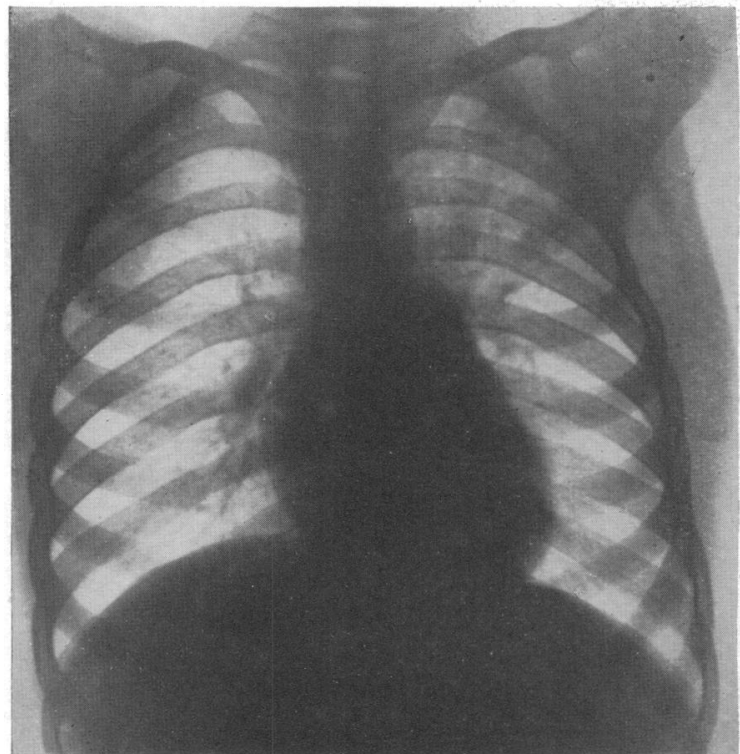

A

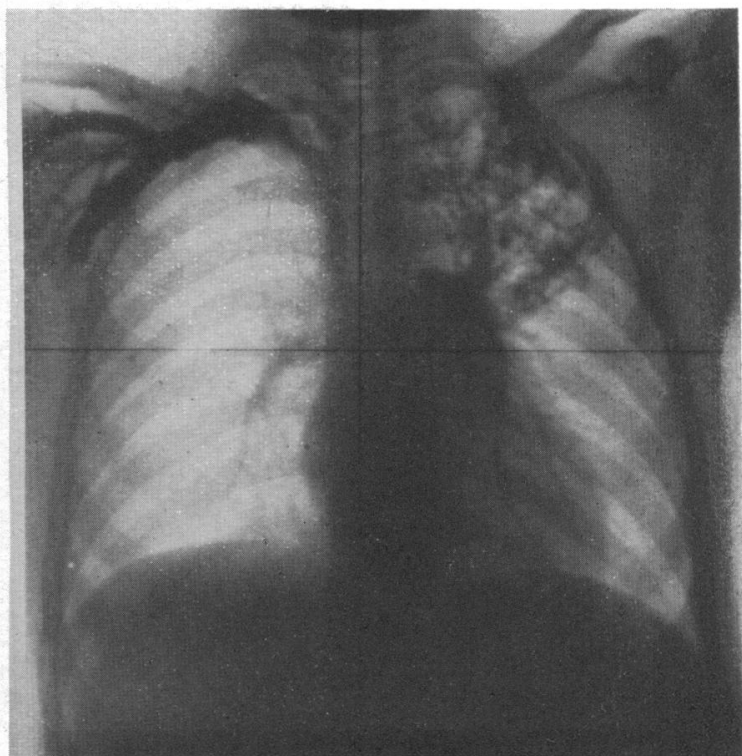

B

Fig. 6.-Case 2, aged 13. (A) Straight X-ray showing streaky radiating shadows in left upper lobe. (B) Angiocardiogram at $2 \mathrm{sec}$. from injection of dye, showing the vascular nature of the shadow in the left upper lobe.

it has been recognized. In 1936 Bowers reported a fatal case in a child of two days old, and in 1938 Rodes described the clinical picture in an adult. The first reported case treated surgically was in 1942 by Hepburn and Dauphinée, where the aneurysm was removed and the condition cured. We have found 29 cases so far reported and although they are not all described in full detail a reasonable survey can be made, to which we are adding these 2 further cases.

With the exception of the case of Bowers (1936), one mentioned by Sweet in the discussion following Maier's (1948) paper, and our second case, the diagnosis has been made in adults, the average age of 26 cases being 29, with extremes of 16 and 51 . Nevertheless it appears that the condition has in most cases been present in childhood, for in 15 cases where the onset of cyanosis is given, it is since birth or early childhood in 8, between the ages of 6 and 14 in 4; and in only 3 is it stated to have begun in adult life. Both sexes are affected but in the reported cases there is a predominance of males. A family history has been suggested in five instances, of which two seem certain, and Goldman's two cases of arteriovenous aneurysm in the lung (1943 and 1947) were brothers.

Cyanosis is the most important feature and its absence was noted in only two cases, that of Duvoir and Picot (1939) who had many visceral angiomata and died of pneumonia aged 16 , and Whitaker's (1947) second case, aged 33, where there was no disability; Maier (1948) makes no mention of this point in his case. It is only in these three that absence of "clubbing" is specifically mentioned, and with a few exceptions where no note is made it is, as might be expected, a feature that goes hand in hand with the degree of cyanosis. Pulmonary osteoarthropathy is reported once by Adams (1944). Polycythæmia in the cyanosed cases is a constant finding with an average of 7.3 million in red cells, the highest figure being 11.4 million in Goldman's (1943) case; the colour index tends to be low, a common finding in polycythæmia. It is likely, however, that although cyanosis is almost a constant finding in reported cases, both the increasing recognition of this condition and the increase in routine X-rays of the chest will reveal earlier cases before cyanosis develops.

It is not surprising that the combination of cyanosis, clubbing, and polycythæmia usually occurring from an early age, often suggests a diagnosis of congenital heart disease, noteworthy exceptions to this misdiagnosis being Smith and Horton's (1939) and Goldman's (1947) cases, both in adults, who had been under treatment for polycythæmia rubra vera. Nothing, however, is found amiss with the heart either on clinical or radiological examination, the sole abnormalities recorded being 


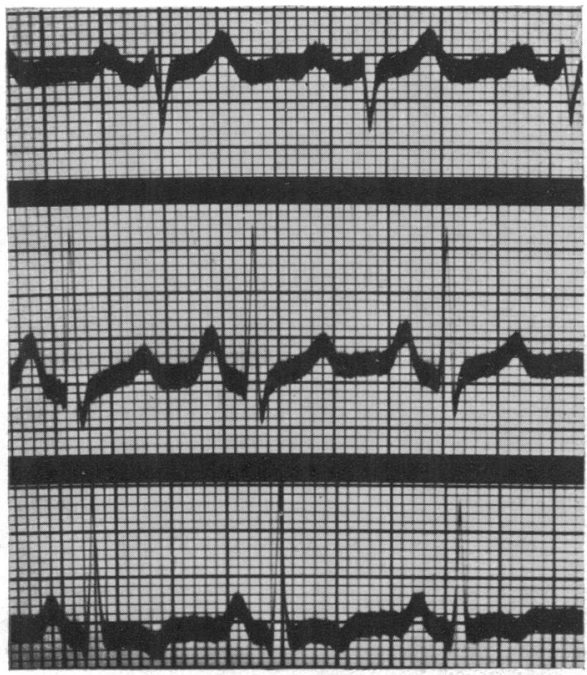

FIG. 7.-Case 1. Standard leads showing marked right axis deviation with large $P$ waves and inverted T III.

by Sisson et al. (1945) with a systolic murmur and enlargement, by Alexander (1945) with enlargement to the left without a murmur, and by Lindgren (1946) whose second case had mitral stenosis. Nor, with the possible exception of Sisson's (1945) case, is there any history of these cases developing heart failure, and though congestive failure was suspected in our first case the cardiac catheterization showed that this was not present. That arteriovenous shunts in the lesser circulation produce so little effect on the heart is in marked contrast to the well recognized strain exerted when similar shunts occur in the systemic circulation. It would, therefore, seem that the combination of cyanosis, clubbing, and polycythæmia, with normal findings on examination of the heart, should suggest the possibility and search for arteriovenous aneurysm of the lung.

The main symptom of the condition is dyspncea which has not preceded the cyanosis in any patient. The degree of disability in many has been slight, particularly considering the degree of cyanosis, and in only 7 of the 29 reported cases would it appear to have been marked. In this respect our first patient appears to have been an unusually severe and late example of the condition. Attacks of dizziness and faintness, not amounting to loss of consciousness, such as were experienced in our first case, have been noted in others. They are presumably due to the increased blood viscosity in polycythæmia and are similar to the attacks so common in morbus cœruleus, though cerebral

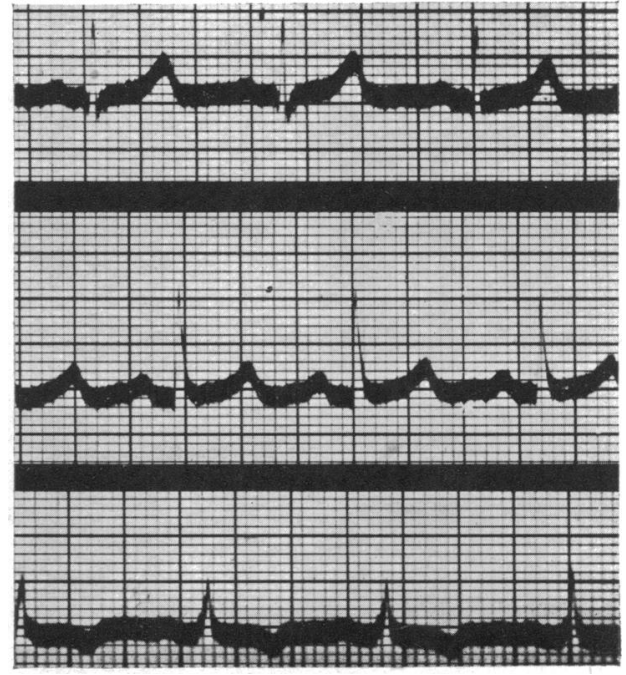

Fig. 8.-Case 2. Standard leads showing no right axis deviation.

thrombosis has not occurred. Alexander (1945), however, reports a case of a patient with marked polycythæmia who died of coronary thrombosis. Epistaxis is not uncommon and occurred frequently in our first patient, once necessitating admission to hospital. This is not unusual in subjects of polycythæmia from any cause, but might well be due, in this particular condition, to angiomata in the nasal mucosa; unfortunately we omitted to examine this site, either in life or post-mortem. Hæmoptysis is reported, and was the cause of death in Rodes' (1938) case, and Lindgren's (1946) third case had been diagnosed and treated as pulmonary tuberculosis on account of this symptom.

In contrast to the negative findings on clinical examination of the heart, a murmur in the lungs, usually systolic but occasionally with a diastolic component, was found in 14 of 23 cases where this sign is mentioned. Similarly in 19 cases where the point is made, associated lesions in other parts were found in 12, the commonest site being on the lips. These two signs, therefore, afforded strong confirmatory evidence of the diagnosis of arteriovenous aneurysm of the lung.

The clinical diagnosis is confirmed by radiology and in no case has a straight X-ray failed to show the lesion in the lung. No doubt in many instances, as in ours, the finding of a shadow away from the heart has been the finger pointing to the answer in a puzzling clinical problem. These are variously described as rounded, with defined or with irregular edges, wormlike, or as an extension of the hilar 
vascular pattern; pulsation may be seen and calcification had developed in our first case. Tomography will clarify and localize, and kymography may show pulsation not visible or established by cardioscopy, but the angiocardiogram is most helpful not only in establishing the vascular nature of a doubtful shadow but in outlining aneurysms close to the mediastinum or hilum or obscured by the heart. Though the experience of Sisson et al. (1945) whose case died as a result of this investigation, must be remembered, an angiocardiogram was amply rewarded in our first case by showing two additional shadows not seen on the straight X-rays or on screening. As multiple shadows have occurred in about half the cases, this investigation would appear to be necessary if surgical intervention is contemplated.

Investigations of the circulatory dynamics have not been common. The circulation time in our first case was normal, which is in accordance with the findings of Makler and Zion (1946) and of Watson (1947). The percentage of blood passing through the shunt was estimated by Maier (1948) to be 58, compared with 25 to 30 in one of Lindgren's (1946) cases and the 80 in our first case. Normal intracardiac pressures were found on catheterization in our case as in Maier's (1948) but unlike our very high figure of 10 to 20 litres a minute, the cardiac output was normal. The increased blood volume which we record was found in all the 8 other estimations made. It is due to the increased cell volume, the plasma volume being unaffected, a distinction from arteriovenous aneurysms in the systemic circulation where both cell and plasma volume are increased with a normal hæmatocrit reading.

The natural course and prognosis of a condition so recently recognized and so readily subjected to surgery is not easy to estimate. From the reported cases it is clear that there is steady, though often slow progression from cyanosis alone, the first sign of a lesion of any size, to symptoms of breathlessness, to restricted activity, and in a few cases to complete disability. It must be remembered that cyanosis alone is disfiguring in the developing child or young adult and there are associated hazards from vascular accidents due to the polycythæmia or the lesion itself. In the 29 cases we have found, 5 died: one from a hæmoptysis at 25 (Rodes); one aged two days from hæmorrhage through the pleura (Bowers); one from coronary thrombosis at 41 (Alexander); one case, not cyanosed, from pneumonia at 16 (Duvoir); and one aged 45, a severe case, as the result of angiocardiography (Sisson). While the average age of the group is 29 , and many had little disability except the cyanosis -notably Smith and Horton's case of a "blue baby" who at 46 had only "some dyspnœa "there is no case older than 51 . It would therefore appear that in those with lesions of any size, where cyanosis is of necessity present, the expectation of life is diminished, though up to the age of 30 the hazards are not great. This would suggest that in these, operation, if it is a reasonable risk, should certainly be contemplated, for if successful, it would mean a cure.

Even allowing for unsuccessful cases which might not so readily be reported, the results are certainly encouraging. Five of the cases died and 19 of the remaining 24 cases had operations. There were 2 fatalities, to which we now add another. In one where the operation is not described, the disappearance of cyanosis is noted as slow, but the others-three with local excision, the remainder with lobectomy or pneumonectomy-are reported as cures although post-operative observations are minimal and followup necessarily short. In arteriovenous aneurysm of the lung where cyanosis is present it would seem therefore that operation is not only indicated but is a reasonable risk. We know that children stand thoracic operations better than adults so that it is important to make the diagnosis at an early age. In those where the condition is recognized without cyanosis-and the quickening appreciation of it will probably reveal cases where an obscure lung shadow is the only finding - the need for surgical intervention would appear small. Whitaker's second patient who refused operation was one of these, and it is by following these types of cases that we shall get a wider appreciation of the natural course of a condition, possibly by no means rare, which so far has been diagnosed only in its more severe degrees.

\section{SUMMARY}

Two cases of arteriovenous aneurysm of the lung are described and discussed with 29 cases previously reported. A clear clinical picture, which has only been recognized in the last ten years, is seen; and the condition is by no means rare. Cyanosis from childhood or early adult life, with clubbing and polycythæmia are the most important features. Physical signs in the heart are uncommon but a murmur may be heard in the chest, corresponding to the invariable finding of an opacity in X-ray of the lungs. Associated vascular lesions in skin, mucous membranes, and particularly the lips are common. The cyanosis is slowly progressive and is followed by dyspnœa, restricted activity, and eventually incapacity. Hazards to life are from anoxæmia, polycythæmia, and hæmorrhage from the aneurysm, rather than from heart failure. The 
commonest misdiagnosis is congenital heart disease when cyanosis develops in early life, as is common, but it may also be mistaken for polycythæmia rubra vera if cyanosis first develops in adult life, or pulmonary tuberculosis when hæmoptysis occurs with the undiagnosed X-ray opacity.

It is successfully treated by removal of the aneurysm, by lobectomy or pneumonectomy.
Surgery is a reasonable risk and indicated in those with lesions large enough to cause cyanosis. The importance of early diagnosis and surgical intervention at an appropriate stage in the disease is stressed.

We are indebted to the numerous colleagues at Guy's Hospital, mentioned above, who co-operated in the investigation and treatment of these two cases.

\section{REFERENCES}

Adams, W. E., Thornton, T. F., and Eichelberger (1944). Arch. Surgery, 49, 51.

Alexander, W. S. (1945). New Zealand med. J., 44, 180.

Bowers, W. F. (1936). Nebraska med. J., 21, 55.

Burchall, H. B., and Clagett, O. T. (1947). Amer. Heart J., 34, 151.

Cleland, W. P. (1948). Thorax, 3, 48.

Duvoir, M., Picot, G., Pollet, L., and Gaultier, M. (1939). Bull. Mém. Soc. méd. Hôp., Paris, 55, 596.

Goldman, A. (1943). Diseases of the Chest, 9, 479. (1947). J. Lab. Clin. Med., 32, 330.

Hepburn, J., and Dauphinée, J. A. (1942). Amer. J. med. Sci., 204, 681.

Janes, R. M. (1944). Brit. J. Surg., 31, 270.
Jones, J. C., and Thompson, W. P. (1944). J. Thorac. Surg., 13, 357.

Lindgren, E. (1946). Acta. Radiol. Stockh., 27, 585.

Maier, H. C., Himmelstein, A., Riley, R. L., and Bunin, J. J. (1948). J. Thorac. Surg., 17, 1.

Makler, P. T., and Zion, D. (1946). Amer. J. med. Sci., 211, 261.

Rodes, C. B. (1938). J. Amer. med. Ass., 110, 1914.

Shenstone, N. S. (1942). J. Thorac. Surg., 11, 405.

Sisson, J. H., Murphy, G. E., and Newman, E. V. (1945). Bull. Johns Hopkins Hospital, 76, 93.

Smith, H. L., and Horton, B. T. (1939). Amer. Heart J., $18,589$.

Watson, W. L. (1947). Surgery, 22, 919.

Whitaker, W. (1947). Thorax, 2, 58. 